CSORBA ROLAND

\title{
Az orvos szerepe \\ a tizennyolc évesnél fiatalabb lányok elleni szexuális büncselekmények bizonyításában
}

A nők és a gyermekek ellen elkövetett szexuális erőszakos cselekedetek világszerte szaporodnak ${ }^{1}$. A fiatalkorúak elleni szexuális erőszak a bántalmazás különösen kegyetlen, váratlan és gyakori módja, amely növekvő aggodalmat kelt nemcsak a nyugati, hanem a keleti társadalmakban is ${ }^{2}$. A nemi erőszak gyakori előfordulása, súlyos egészségkárosító hatása és az áldozat egész életére kiható következményei miatt a kérdés az elmúlt évtizedben az orvosi és a büntetöjogi gyakorlat középpontjába került. Magyarországon körülbelül minden tizedik nőt bántalmaz a házastársa vagy élettársa ${ }^{3}$. A közhiedelemmel ellentétben a szexuális büncselekmények nagyobb része többszörös, krónikus előfordulású, ezeket ráadásul családon belül okozzák. Ez sokkal több fiatalkorú életét követeli, mint a hasonló életkorúak rosszindulatú megbetegedései ${ }^{4}$.

Ritkán telik el hét anélkül, hogy a sajtó ne adna hírt egy klasszikus gyermekbetegség gyógyítását szolgáló, új reményteli kezelési eljárás felfedezéséről. A gyermekek elleni szexuális erőszak megelőzéséért, megszüntetéséért tett erőfeszítésekről, még kevésbé a kérdésben elért szakmai sikerekről azonban alig hallhatunk. A nemi erőszak általában csak akkor kerül a figyelem középpontjába, amikor már tragédia történt. Magyarországon minden második, halállal végződő erőszakos bűncselekmény „családi ügy”. A brutálisan megölt áldozatok fele nem csupán ismerte, hanem egykor szerette is gyilkosát, hiszen szülője, gyermeke, testvére, házastársa, élettársa volt. ${ }^{5}$

A fiatalkorúak által elszenvedett szexuális bántalmazásra az Egyesült Államokban és Nyugat-Európában évtizedekkel korábban gyermek- és nőjogi

\footnotetext{
1 Etienne G. Krug - Linda L. Dahlberg - James A. Mercy - Anthony B. Zwi - Rafael Lozana: World report on violence and health. World Health Organization, Geneva, 2002. http://www.who.int/violence_injury_prevention/violence/world_report/en/introduction.pdf

2 Carol Djeddah - Paola Facchin - Cristina Ranzato - Claude Romer: Child abuse: current problems and key public health challenges. Social Science \& Medicine, vol. 51, 2000, pp. 905-915.

3 Morvai Krisztina: Terror a családban. Kossuth Kiadó, Budapest, 1998, 111. o.

4 The neglect of child neglect. The Lancet, vol. 361, 2003, p. 443. http://www.thelancet.com/journals/lancet/article/PIIS0140-6736(03)2912492-0/fulltext

5 Morvai Krisztina: i. m. 13. o.
} 
mozgalmak hívták fel a figyelmet. Hazánkban csak az utóbbi években kerültek nyilvánosságra konkrét és megdöbbentő esetek.

A növekvő nyilvánosság következtében sokan azt a téves következtetést vonják le, hogy növekszik a gyermekek ellen elkövetett szexuális büncselekmények száma. Valójában az információáramlás feltételeinek javulásának következménye, hogy az eddig titkolt, fel nem tárt esetek napfényre kerülnek. Korábban ezek az áldozatok úgy gondolták, hogy a helyzetük egyedi, szégyellni- és titkolnivaló.

A gyermekek elleni bántalmazással kapcsolatba kerülő egészségügyi dolgozók feladata nehéz és sokrétü, mivel a gyakran nehezen értékelhető jelek, a netán alaptalan súlyos vád elkerülése, a megoldás nehézségei a bizonyított esetekben, a szakmai elszigeteltség és a szexuális bántalmazás ma is tabuként kezelt megítélése miatt nem könnyü felismerni a bántalmazást.

Jóllehet a gyermekbántalmazás magában foglalja a fizikai, érzelmi és szexuális bántalmazást, valamint a gyermekek elhanyagolását, dolgozatomban kiemelten a gyermekek és fiatalkorúak ellen elkövetett szexuális bántalmazással, zaklatással foglalkozom.

Annak ellenére, hogy a szakirodalomban már 1975 óta ismert a kórkép ${ }^{6}$, Magyarországon még nem történt átfogó, populációalapú vizsgálat, az ismert és eddig felderített esetek a szexuális zaklatás áldozatainak mindössze töredékét ölelik fel. Ez pedig csupán a jéghegy csúcsa, a gyermekek elleni szexuális bántalmazás néma járványként söpör végig a világon, és ez alól hazánk sem kivétel. Itthon még mindig sokan úgy gondolják, hogy alig van jelen, inkább csak importáru, a magyar fiatalokat nem fenyegeti, így nem kell vele foglalkozni. Munkám során tett megfigyeléseim azt igazolják, hogy a külföldi tanulmányok tapasztalatai hazánkban is érvényesek. A gyermekekkel foglalkozó szakembereknek nincs elegendő és adekvát ismeretük a szexuális visszaélésekről, az áldozatok és elkövetők jellemzőiről, a bűncselekmények felismeréséről, kezeléséről és az áldozatok rehabilitációjáról. A legtöbb kriminológus szerint a nők ellen elkövetett eröszakos cselekmények a legkevésbé dokumentált bünügyek?

A szexuális bántalmazás pontos előfordulásának ismerete és a gyermekek elleni erőszak megfelelő orvosi és jogi megközelítésének megteremtése alapvető egészségügyi és társadalmi, nemzeti követelmény.

6 Suzanne M. Sgroi: Sexual molestation of children: The last frontier in child abuse. Children Today, vol. 44, 1975, pp. 18-21.

7 David Finkelhor: A sourcebook on child sexual abuse. Sage, Beverly Hills, 1986 
Az elsődleges orvosi ellátást végző orvos szerepe rendkívüli jelentőségüvé válhat a büntetőeljárásban, hiszen közvetlen információkat észlel, amelyek későbbi bizonyítékként történő felhasználására feltétlenül szükség lesz.

\section{Kutatás és a vizsgálat az orvos szemével}

A hétszázezres Hajdú-Bihar megyében a Debreceni Egyetem Orvos- és Egészségtudományi Centrumának Szülészeti és Nőgyógyászati Klinikája az egyetlen intézet, amelyben gyermeknőgyógyászati ellátás folyik. Elemeztük az 1986. január 1. és 2006. december 31. között a klinikánkon szexuális bántalmazás miatt megjelenő tizennyolc évesnél fiatalabb lányok adatait. A munkánkat a vizsgálati periódus első tíz évében az adatok retrospektív gyüjtésével, majd 1996-tól a betegek adatainak prospektív feldolgozásával végeztük. A szexuális bántalmazásnak kitett lánybetegek kórtörténeteit kiemeltük, a büncselekményt és annak körülményeit elemeztük, és az eseteket a bírósági eljárás végéig követtük.

A klinikán az áldozatok ellátása részletesen kidolgozott standard alapelvek alapján történt. A protokoll magában foglalta a gyermekbántalmazás meghatározását, a vizsgálat célját és menetét. A következő jellemzőket rögzítettük: az áldozat életkora és foglalkozása; az elkövető életkora és foglalkozása; családi kapcsolat a fiatalkorú áldozat és az elkövető között; a szexuális bántalmazás gyakorisága; a szexuális zaklatás típusa; a bűntény helyszíne; a bűncselekmény elkövetésének ideje napszak és évszak szerint; az áldozat és az őt a klinikára kísérő személy közötti családi vagy egyéb kapcsolat; és a klinikai vizsgálat eredményei. Ugyancsak rögzítettük az elkövetés és a vizsgálat között eltelt időintervallum hosszát, és a nőgyógyászati vizsgálat eredményét is. A vizsgálatot legtöbbször a klinika gyermeknőgyógyászati szakrendelésének munkatársai végezték. Az esetek orvosi ellátása a sérülésnek megfelelően, standard szempontok szerint történt. Ugyancsak azonos módon került sor a teljes kórelőzmény rögzítésére, beleértve az orvosi és szociális anamnézist, és azonos irányelvek szerint zajlottak a vizsgálatok.

A kórelözmény pontos felvétele - az esetleges büntetőjogi következmény miatt - rendkívül fontos. A fiatalkorú saját szavaival előadott történetét szóról szóra rögzítettük, figyelembe véve az áldozat fejlettségi szintjét, életkorának megfelelő szókincsét és értelmi képességét. Figyelmet fordítottunk az áldozat és a kísérő viselkedésére, magatartására (félelem, szorongás, kétségbeesés). 
A szülő vagy a kísérő által elmondott történetet ugyancsak rögzítettük. Nagy jelentőséget tulajdonítottunk a nyugodt, alapos, minden apró részletre kiterjedő kikérdezésnek. Az anamnézisfelvétel során az orvosnak olyan körülményt kell teremtenie, hogy az áldozat képes legyen minél pontosabban leírni a bántalmazás folyamatát. Gyakorlatunkban általános kérdésekkel felmértük a kognitív képességet, majd próbáltuk meggyőzni az érintettet arról, hogy segíteni akarunk neki. A vizsgáló orvosnak nyugodtan elmondhatta, ha nem tudott vagy nem értett valamit, sőt módja volt kijavítani az orvost, ha az nem jól értelmezett valamilyen részletet. Mindig meg kell győződnünk arról, hogy az áldozat meg tudja különböztetni az igazságot a hazugságtól, hogy ismeri a testrészeket, a helyragokat annak érdekében, hogy a korának megfelelő szóhasználattal tudja előadni a történteket; a rögzített beszámolónak nagy jelentősége van. Fontos, hogy az interjú nyelvezete egyszerü legyen, nyitott kérdéseket tegyünk fel, és fokozatosan irányítsuk, koncentráljuk kérdéseinket az esetleges szexuális zaklatásra. Kerülnünk kell az elöítéletet, a kritizálást és a minősítést. Az elmondott történetnek tartalmaznia kell a büncselekmény idejét, helyét, körülményeit, az elkövetö jellemzőit és a zaklatás típusát, az esetleges erőszak jellegét. Hasznos a beszélgetést a következő kérdésekkel kezdeni: „Tudod, hogy miért vagy itt ma az orvosnál? El tudod mondani, hogy mi történt és hogyan kezdődött?” A bántalmazás jellegéből adódóan legtöbbször kiderül, hogy nemcsak egy alkalommal történt a bántalmazás, hanem az orvosnál való jelentkezést kiváltó legutolsó esemény előtt már rendszerint meghatározott ideje tartott.

A fizikális vizsgálat tartalmazta az áldozat teljes testének átfogó vizsgálatát, a szexuális fejlettség megítélését, a szexuális és egyéb bántalmazás jeleinek kutatását, az esetleges sérülések azonosítását, különös tekintettel az introitus és a szüzhártya kolposzkópos képére. A gyermeket megnyugtatja, ha a vizsgálatot édesanyja vagy a gondviselöje jelenlétében végezzük. Szabály, hogy a vizsgálatot teljesen meztelenül végezzük. Az áldozat teljes testfelületén kerestük a fizikai bántalmazás nyomait, zúzódások, hematómák, duzzanatok, horzsolások, fognyomok és fojtogatás nyomait. Ezeket anatómiai elhelyezkedésük és kiterjedésük alapján írásban pontosan rögzítettük.

A nemi szervek vizsgálatára a különböző pozíciókban került sor. A gyermeket alaposan megtekintettük hanyatt, békaláb helyzetben, esetleg az édesanyja ölében, hanyatt, térd-mell helyzetben, és idösebb áldozatok esetében kőmetsző helyzetben, lábtartók használatával. A hanyatt végzett vizsgálómódszerek egyike a nagyajak-szétválasztásos módszer. A vizsgáló ujjait mindkét nagyajakra helyezi és azokat laterális irányban távolítja. A másik technika a nagyajak-széthúzásos módszer, amelynek során a nagyajkakat uj- 
jainkkal megfogjuk, és finoman laterálisan és lefelé húzzuk öket. A hüvely feltárását csak idősebb lányok esetében használtuk, akiknek a fejlettségi szintje megfelelő volt ( $>$ Tanner III. std.). A vizsgálatok tapintatosan, félelemkeltés nélkül, legtöbbször az édesanya jelenlétében történtek, mindig támaszkodva a gyermek együttmüködésére. A nőgyógyászati vizsgálat során feltérképeztük a gátat, különös tekintettel a vérzésekre, hematómákra, horzsolásokra, szüzhártyasérülésekre. A szüzhártya és a posterior fourchette területét kolposzkóppal vizsgáltuk.

A vizsgálat tartalmazta továbbá az esetleges terhesség vizeletteszttel vagy ultrahanggal történő vizsgálatát, igazságügyi bizonyítékok gyüjtését (spermium, nyál, szennyező anyagok, ruházat, egyéb bizonyítékok). Spermiumkutatást négy helyről végeztünk: hüvelybemenet/hymenális gyürü, hüvelyboltozat, nyakcsatorna és végbélnyílás. Mindezt az ellátást igénylő sérülések sebészi kezelése és profilaktikus intézkedések követték (sürgősségi fogamzásgátlás, tetanus anatoxin, nemi úton terjedö betegségek antibiotikum-profilaxisa). A klinikánkon alkalmazott protokollt az 1. számú táblázat foglalja össze.

A vizsgálatok eredményét a gyermeknőgyógyászati szakrendelésen való első megjelenéskor, majd minden ismételt vizsgálatkor dokumentáltuk. A leletek archiválása és hivatalos kérésre történő kiadása volt az ellátás utolsó lépése.

Az orvosi vizsgálat csupán egy része a szexuális bántalmazás felderítésére irányuló multidiszciplináris együttmüködésnek. Fő feladata, hogy felderítse és kezelje az esetleges sérüléseket és fertőzéseket, igazságügyi orvosi bizonyítékokat gyüjtsön, szürje az esetleges nemi úton terjedő betegségeket, biztosítsa a gyermeket és a családot a gyermek egészségi állapotának gyors javulása felől, és a későbbi bírósági eljárás számára pontos dokumentációt nyújtson.

A bántalmazott gyermekek vizsgálatának ismertetett módszerén túl tanulmányoztuk a gyermekeket érő szexuális bántalmazás, molesztálás és a nemi erőszak közötti különbségeket, rámutatva a büncselekmények diagnosztikai nehézségeire. A büncselekmények jogi eljárásainak eredményeit is értékeltük. Az orvosi és a bírósági adatokat folyamatosan, párhuzamosan figyeltük és összehasonlítottuk.

\section{A vizsgálatok eredményei}

Az 1986 és 2006 között eltelt húsz évben kétszázhatvanhat tizennyolc évesnél fiatalabb lány ellátására került sor a klinika gyermeknőgyógyászati szakrendelésén szexuális bántalmazás vagy erőszak miatt. 
1. számú táblázat

Szexuális bántalmazás ellátásának protokollja

a Debreceni Egyetem Orvos- és Egészségtudományi Centrumának

Szülészeti és Nőgyógyászati Klinikáján

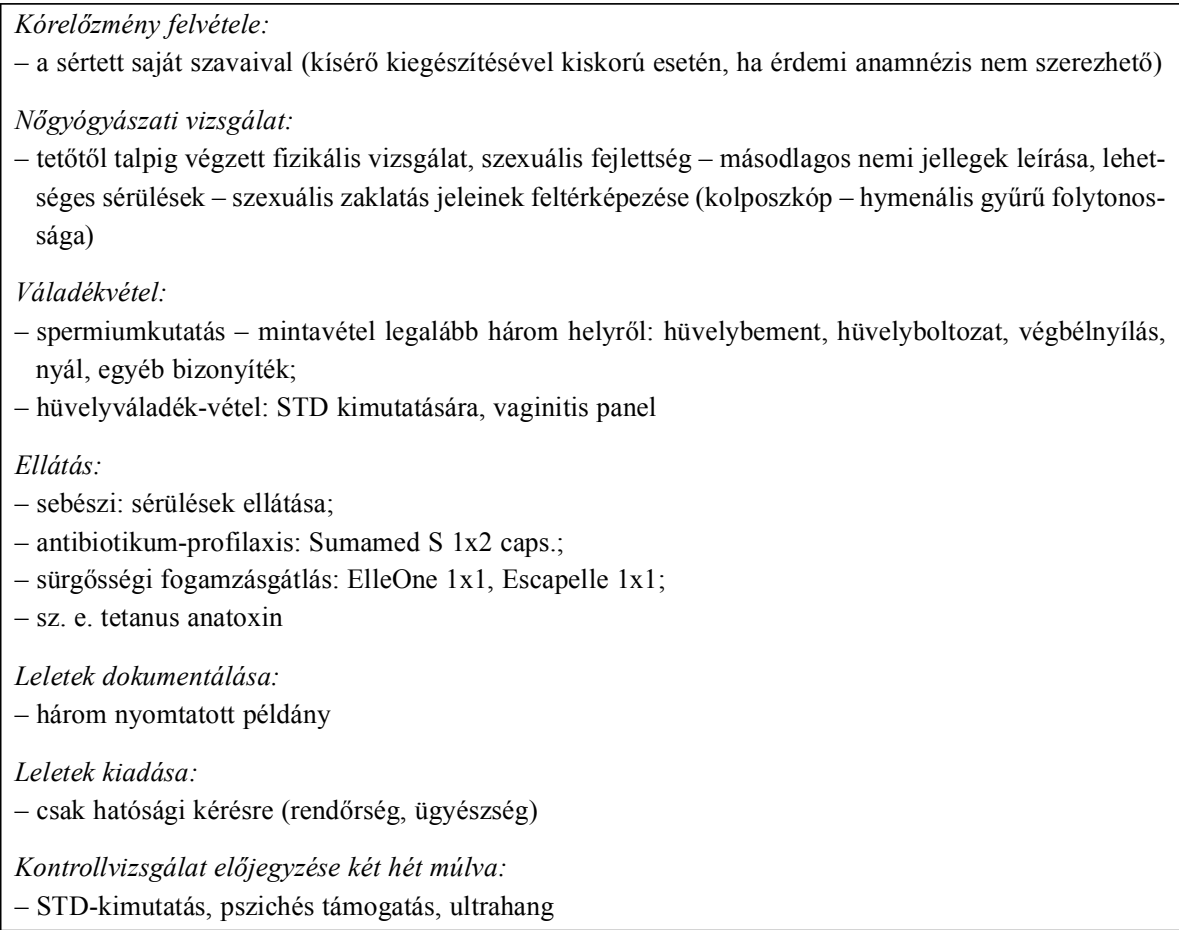

Száztizennégy esetben az áldozat ismerte az elkövetőt, nyolcvanhétben pedig ismeretlen a büncselekmény tettese. Hetvenöt esetben (huszonnyolc százalék) családtag volt a szexuális zaklatás elkövetője. A fiatalok negyvenöt százaléka a tizenegy és tizennégy év közötti korcsoportba tartozott, a legfiatalabb áldozat másfél éves volt. Közülük kétszázhat áldozat tanuló volt, három szellemi fogyatékos, hat még óvodás, huszonegyen már dolgoztak, és harminc áldozatot eltartottak vagy munkanélküli volt. A nagy arányban (huszonnyolc százalék) előforduló családon belüli erőszak esetében az elkövető az édesapa (negyvenkilenc százalék), vagy a mostohaapa (harminckét százalék) volt.

A büncselekmények gyakoriságát elemezve megállapítható, hogy az esetek több mint negyedében (huszonkilenc százalék) a szexuális zaklatás ismétlödött. Az egyszeri esetek elkövetésének időpontját tekintve kiderül, hogy a szexuális büncselekmények legtöbbször délután és éjszaka történnek, legin- 
kább a nyári és a téli szünidő alatt, amikor a gyermekek az iskolai szünidejüket töltik. A cselekmények helyszínét vizsgálva kiderült, hogy a büncselekmény az esetek huszonhat százalékában az áldozatok otthonában történt. Az áldozatot legtöbbször az édesanyja vagy a rendőrség kísérte be a klinikára. Az áldozat és/vagy az őt kísérő személy által előadott kórelőzmény alapján a szexuális büncselekmények típusuk szerint a következőképpen oszlottak meg: az esetek hetvenegy százalékában hüvelyi coitus történt, huszonkilenc százalékában szexuális fajtalankodás, míg az esetek harminckét százalékában mindezt fizikai sérülés is kísérte. Az elkövetés és a klinikai vizsgálat között eltelt idő hossza változó volt, százharminc áldozat esetében (negyvenkilenc százalék) azonnali, adekvát, sürgősségi ellátást tudtunk nyújtani, negyvennyolc lány (tizennyolc százalék) hetvenkét órán belül jelentkezett, míg nyolcvannyolc (harminchárom százalék) áldozat esetében csak hetvenkét órán túl került sor a szakszerü vizsgálatra.

Az áldozatok fizikális vizsgálata során a következő szempontokra összpontosítottunk: az esetleges sérülések meghatározása és sebészi ellátása, igazságügyi bizonyítékok gyüjtése, spermiumkutatás és mintavétel a korábban leírt szempontok alapján. A vizsgált esetek között két terhességet találtunk. Fizikai sérülést nyolcvanöt esetben (harminckét százalék) detektáltunk, ezek közül kettő igényelt sebészeti ellátást. Az utóbbi két eset egyikében az édesapa által megerőszakolt másfél éves kislánynál a vulvát és rectumot érintő gátrepedést észleltünk. ${ }^{8}$ A laboratóriumi vizsgálatok negyven esetben (tizenöt százalék) igazolták spermiumok jelenlétét.

Büntetőeljárás: a húszéves vizsgálati időszak alatt a szexuális bántalmazást százhuszonhét esetben követte feljelentés és bírósági, büntetőeljárás. A jogerösen elítélt elkövetők száma hatvannyolc volt, ez az esetek huszonhat százaléka. Az elítéltek ügyében harminckét esetben nemi erőszak volt a vád, hatban természet elleni fajtalankodás, míg harminc esetben fiatalkorú megrontása szerepelt a vádiratban.

A szexuális bántalmazás áldozatait a szerint is csoportosíthatjuk, hogy az elkövető a családi vagy ismerős körből kerül ki, vagy az áldozat számára ismeretlen tettesről van szó. Az orvosi terminológiában az előbbi csoportra gyakran a zaklatás, molesztálás, szexuális bántalmazás kifejezést alkalmazzuk, míg a második csoportot ért sérelmet leegyszerüsítve nemi erőszaknak nevezzük, ami azonban a jogi fogalommeghatározásnak nem felel meg. Az

8 John McCann - Joan Voris - Mary Simon: Genital injuries resulting from sexual abuse: a longitudinal study. Pediatrics, vol. 89, 1992, pp. 307-317. 
esetek nagy részében (hatvannyolc százalék) erőszaknak nyoma sincs, mivel a gyermekeket molesztálók a gyermekek által ismert, szeretett és bizalmat keltő személyek voltak. Hetvenöt esetben (huszonnyolc százalék) a szexuális bántalmazással vádolt személy családtag volt, a büncselekmény otthon történt. Ezekben az esetekben az első vizsgálat szinte mindig késik, a gyermek nem árulja el a szeretett egyént, így az esetek túlnyomó többségében igazságügyi bizonyítékot sem lehet találni. Ezekben az esetekben típusos a büncselekmény többszörös előfordulása (huszonkilenc százalék). Mivel a gyermek csak későn vagy egyáltalán nem fedi fel a közös titkot, így a vizsgáló az eltelt idő hossza miatt nem képes a korábbi trauma jelét dokumentálni. Bizonyított tény, hogy az egyszerü, nem teljes szüzhártyaszakadás kilenc, a teljes szakadás huszonnégy-harminc nap alatt spontán meggyógyul. ${ }^{9}$

A szexuális zaklatás utáni fizikális leletek hiányának vagy alacsony számának további oka a szexuális molesztálás természete. A büncselekmény legtöbbször nem társul olyan erôs fizikai kontaktussal, hogy az fizikai tüneteket, észrevehető sérüléseket hozzon létre (érintkezés nélküli formák, orális abúzus, pornográf fotók). Egy amerikai tanulmány szerint százkilencvenkét hüvelyi behatolással járó szexuális erőszakon áteső lány közül mindössze négy (két százalék) mutatott egyértelmü tünetet, mint szüzhártyaszakadás, -perforáció ${ }^{10}$. Külön figyelemmel kell kísérni azokat az eseteket, amikor az elkövető családtag. A vizsgálati periódus alatt hetvenöt ilyen esetet találtunk. A legtöbb áldozat tizenegy és tizennégy éves volt, míg a legfiatalabb alig volt másfél éves. Mivel ezek az arányok bizonyára csak a jéghegy csúcsát képviselik, az aktuális szám minden bizonnyal a hetvenöt többszöröse. Ilyenkor a legtöbb esetben a fiatalkorú lány állandó fenyegetettségről számol be; megveri, megbünteti az elkövető, ha bárkinek mesélni mer a cselekményröl. „14 éves kislányt veréssel megfenyegettek, majd egy hét alatt kb. hússzor közösültek vele, szájon át is.” „Én Sanyi bácsit úgy ismertem, hogy hozzánk nagyon jó, mintha édesapánk lett volna, úgy szeretett. Többször megpuszilgatott, hozott nekünk süteményt, cukrokat. Délelőtt Sanyi bácsi elég ittas volt, odahívott magához, puszilgatott, simogatott, mondta: vetkezzél le, mert meg... Félelmemben kiszaladtam, de Sanyi bácsi utánam jött, kezében egy szíjostorral." Sok esetben a gyermek ajándékot kap, az elkövető érzelmileg is zsarolja. A fiatal nem tudja, hogy a szexuális abúzus káros és bünös tevékenység, sok mindent megtesz a felnőtt kérésére, annak ellenére, hogy az ellenkezik az ő akaratával.

9 Uo.

10 Susan S. Glander - Mary Lou Moore - Robert Michielutte - Linn H. Parsons: The prevalence of domestic violence among women seeking abortion. Obstetrics \& Gynecology, vol. 91, 1998, pp. 1002-1006. 
Ezért nem mernek feljelentést tenni, sajnos az édesanyák rendszerint túl későn szereznek tudomást a helyzetről. Ugyanakkor ők maguk is félnek a hátrányos anyagi helyzettől, mindazon gyötrelmektől, amelyek a családra várnak, ha a családföt mint fö pénzkeresőt esetleg a börtönbe juttatják. Ez veti meg az alapját a többszörös, titokban maradt, folytatólagosan elkövetett szexuális bántalmazásnak. A szexuális zaklatások legtöbbször nyáron és télen következnek be, amikor a gyermek iskolai szünetét élvezi (az esetek ötvennégy százaléka nyáron, huszonegy százaléka télen).

Vannak olyan rizikófaktorok, amelyek hajlamosabbá teszik a gyermekeket a szexuális zaklatásra. Így könnyebben áldozattá válik a fiatal, ha elvált szülök gyermeke; ha mostohaszülő van a családban; ha tinédzserkorúak a gyermek szülei; ha maga a gyermek fogyatékos vagy pszichológiailag sérülékenyebb az átlagnál; ha magára hagyott, izolálódott; ha az édesanyja elfoglalt; ha csekélyek a párkapcsolatról alkotott ismeretei; esetleg drogot vagy alkoholt fogyaszt. Az elkövetés időpontja összhangban van ezzel: a legtöbb büncselekmény az iskola után következik be délután vagy este, amikor még a szülők dolgoznak, vagy amikor az iskolai szünetben a gyermekfelügyelet nem megoldott.

A családon belüli bántalmazással ellentétben az idegen elkövető által okozott szexuális bántalmazás áldozatai (harminchárom százalék) rendszerint azonnal jelentkeznek az orvosnál, és nagy százalékukban találhatók igazságügyi bizonyítékok. Betegeink között idegen elkövető volt nyolcvanhét esetben (harminchárom százalék), közülük negyven esetben (tizenöt százalék) volt kimutatható spermium a hüvelyi keneteken. Ezeket az áldozatokat valamelyik családtag kíséri, az azonnali vizsgálat elvégezhető. Az igazságügyi bizonyítékok gyüjtése a szexuális bántalmazás után hetvenkét órán belül nagyobb valószínűséggel eredményre vezet, de a DNS-technika bevezetése óta ez az idő napokkal, hetekkel is kitolódhat.

Az elmúlt húsz évben kétszázhatvanhat esetet százhuszonhét alkalommal (negyvennyolc százalék) követett rendőrségi feljelentés. A jogerősen elítéltek száma hatvannyolc volt (huszonhat százalék). Az elkövetők elleni büntetőeljárás évekig zajlott. A feljelentések és a büntetőügyek alacsony száma és a magyar igazságszolgáltatásban ismert hosszú döntési idő akadályozza az események ismétlődésének vagy hasonló bántalmazások bekövetkezésének hatékony megelőzését. 


\section{Az áldozatok ellátásának orvosi és multidiszciplináris elemei: a felismerés és a terápia tanulságai}

A szexuális bántalmazásra utaló eseményekre az anamnézisben rá kell kérdezni, akár burkolt, akár közvetlen formában. A közelmúltban publikált külföldi tanulmányok szerzői egyetértenek abban, hogy az áldozatok várják az esetleges szexuális zaklatást feltáró kérdéseket, de ezek az esetek nagy részében elmaradnak. ${ }^{11}$ A szülöknek, az iskolai nevelőknek és az orvosoknak egyaránt fel kell figyelniük a gyermekkel való rossz bánásmódra, az esetleges szexuális bántalmazására utaló apró jelekre. A helyzetet nehezíti, hogy a testi jelek hiánya nem zárja ki a bántalmazás lehetőségét; a jelek sokszor nem egyértelműek; az áldozattól nem várható a gyanú megerósítése, így a szakembernek minden gyanús esetben gondolnia kell a szexuális és egyéb bántalmazási formákra. Mindazonáltal senkit nem szabad alaptalanul megvádolni, tisztában kell lenni azzal is, hogy a vélt áldozat sem mindig szavahihetô. ${ }^{12} \mathrm{~A}$ bántalmazás gyanújelei a gyermek életkorával párhuzamosan eltérő formákban jelenhetnek meg, pubertáskorban még nehezebb a normális magatartás és deviáns viselkedés elkülönítése. A gyanújelek lehetnek általánosak és specifikusak, jelentkezhetnek a szomatikus, érzelmi és viselkedésbeli szinteken, illetve azok kombinációjában. Azonnal szakemberhez kell fordulni, ha a gyermeknél a következő általános viselkedésbeli jeleket vesszük észre: alvászavarok, koncentrálási nehézség, depresszió, iskolai teljesítmény romlása, passzivitás, zárkózottság, bizalmatlanság, félelem, koraérett magatartás, otthonról való menekülés (2. számú táblázat). Ismernünk kell a gyanús szülői magatartások jellemzőit is: orvosi, védőnői tanácsok be nem tartása; a szülő által előadott történet nem egyeztethető össze a sérüléssel; a gyermek és a szülő által elmondott kórtörténet nem egyezik; a kórházba kerülő gyermek látogatásának elmulasztása.

\footnotetext{
11 Ursula M. Peschers - Janice Du Mont - Katharina Jundt - Mona Pfürtner - Elizabeth Dugan Günther Kindermann: Prevalence of sexual abuse among women seeking gynecologic care in Germany. Obstetrics \& Gynecology, vol. 101, 2003, pp. 103-108.; Joyce A. Adams: Medical evaluation of suspected child sexual abuse. Journal of Pediatric \& Adolescent Gynecology, vol. 14, 2004, pp. 191-197.; Joyce A. Adams: Evolution of a classification scale: Medical evaluation of suspected child sexual abuse. Child Maltreatment, vol. 6, 2001, pp. 31-36.

12 Elek Balázs: A vallomás befolyásolás a büntetőeljárásban. Tóth Könyvkereskedés és Kiadó Kft., Debrecen, 2008, 180. o.; Elek Balázs: A személyi bizonyítékok megbízhatósága a büntetőperekben. Rendészeti Szemle, 2009/3., 87-102. o.
} 
2. számú táblázat

A gyermeknél észlelhető általános gyanújelek

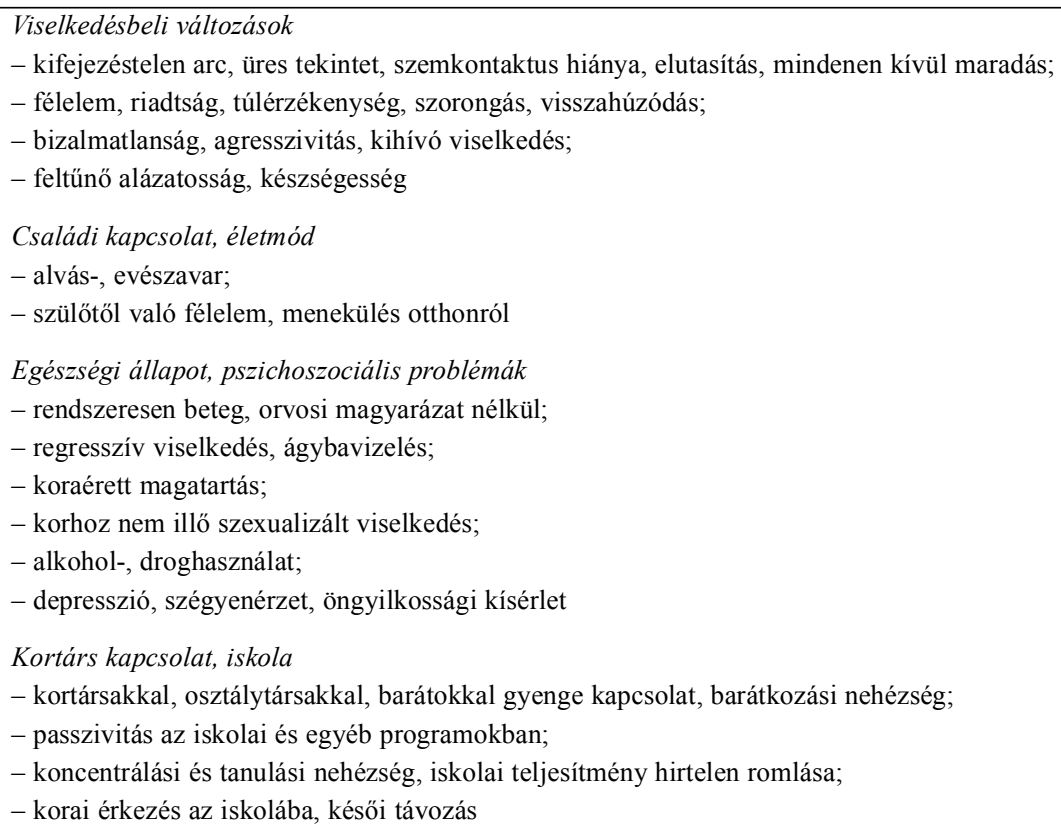

A bántalmazásra fizikai jelek is utalhatnak, ezeket a 3. számú táblázat tartalmazza. Különösen a következők esetén kell gyanakodnunk esetleges szexuális bántalmazásra: a szülő a sérülés után csak később fordul orvoshoz; a gyermek és a szülő egymástól eltérően számol be a sérülésről; a sérülés típusa nem egyeztethető össze az előadott történettel; valamint a szülő mindig másmás orvoshoz, különböző kórházakba viszi a gyermeket. ${ }^{13}$

A szexuális bántalmazás nem specifikus gyanújelei közé tartoznak az elöbbiekben vázolt általános viselkedési jelek, a szexuális zaklatás következményei, például alhasi fájdalom, visszatérő fájdalmas vizelés és húgyúti fertőzések, a nemi szervek fájdalma és viszketése.

A specifikus jelek egyértelmüek: nemi szervek és a végbélnyílás sérülése, gyulladása, terhesség és nemi úton átvihető betegségek.

\footnotetext{
13 Aszódi Imre: A szexuális büncselekményekkel kapcsolatos néhány kérdés. Magyar Nőorvosok Lapja, 2001/64., 71-74. o.; Jan Bays - David Chadwick: Medical diagnosis of the sexually abused child. Child Abuse \& Neglect, vol. 17, 1993, pp. 91-110.
} 


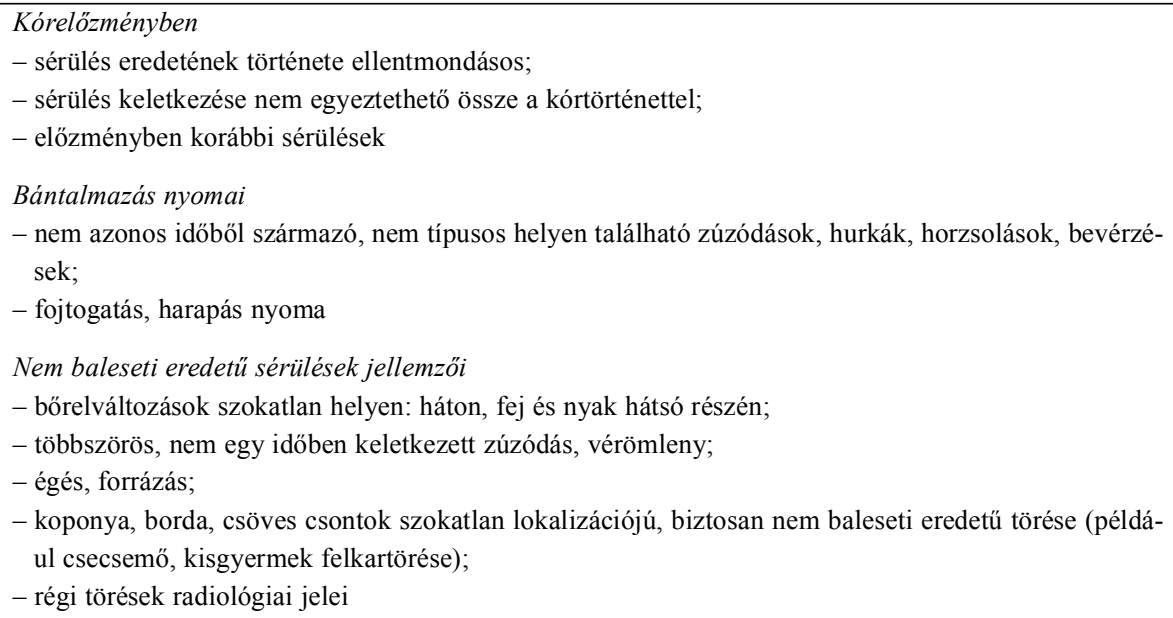

Az anamnézisfelvétel és a vizsgálati leletek alapján a szexuális bántalmazás valószínüségét a 4. számú táblázatban foglaltuk össze. ${ }^{14}$

\section{Javaslatok}

\section{az orvosi vizsgálat bizonyító erejének erősítésére}

A bántalmazott gyermek ellátása és rehabilitációja kijelölt centrumban történjen, a leírt protokoll alapján, amelyet a következőkkel egészítenék ki.

- Rendkívüli fontosságát figyelembe véve az első vizsgálat fotodokumentáció használatával történjen. A vizsgálat során videokolposzkóp használata kifejezetten elönyös, mert az áldozat számára a vizsgálatot könnyebben elviselhetővé teszi, mivel a gyermek számára is látható a vizsgálat és a kenetvétel.

- A vizsgáló módszereket ki kell egészíteni a térd-mell helyzetben végzett vizsgálattal. Ebben a pozícióban a hüvely elülső fala eltávolodik a hátsó faltól és a szüzhártya vizsgálandó része (posterior fourchette) a gravitáció miatt jobban láthatóvá válik. A hymenális gyürüt a szüzhártya határának jobb megítélése érdekében sóoldattal be is nedvesíthetjük. Az igazságügyi bizo-

14 Joyce A. Adams: Sexual abuse and adolescents. Pediatric Annals, vol. 26, 1997, p. 299. 
Nincs bizonyíték

- Normál vizsgálati lelet, nincs szexuális zaklatásra utaló kórelőzmény, nincs szemtanú, nincsenek viselkedésbeli eltérések.

- Más eredettel magyarázható nem specifikus vizsgálati lelet, nincs szexuális bántalmazással kapcsolatos vallomás, nincsenek viselkedésbeli eltérések.

- A gyermek veszélyeztetettnek tekinthető, de nincs pozitív anamnézis, és csak nem specifikus viselkedésbeli eltérések.

- A sérülés fizikális lelete összhangban van a balesetre vonatkozó anamnézissel, ami egyértelmű és hihetô.

Lehetséges bántalmazás

- Normál vagy nem specifikus vizsgálati lelet, jelentős viselkedésbeli eltérésekkel, főleg szexualizált magatartás, de a gyermekbántalmazásra vonatkozó anamnézist adni nem tud.

- Condyloma accuminatum vagy HSV 1 okozta anogenitális léziók egy prepubertás korban lévő gyermekben, szexuális bántalmazásra vonatkozó anamnézis nélkül, egyébként normális vizsgálati lelettel.

- A gyermek tesz vallomást, de az a gyermek szintjéhez képest nem elég részletes, vagy nem következetes.

- Gyanús vizsgálati lelet anélkül, hogy szexuális abúzust vagy viselkedésbeli eltérést igazolhatnánk.

Valószínü bántalmazás

- A gyermek világos, részletes vallomást tesz, fizikális jelek meglétével vagy anélkül.

- Erősen gyanús vizsgálati leletek, eltérések, szexuális bántalmazásra vonatkozó anamnézissel vagy anélkül, áthatoló sérülésre vonatkozó anamnézis nélkül.

- Kétéves kor feletti áldozat esetében a genitális váladék tenyésztése: Chlamydia trachomatis pozitív.

- A genitális tájékról vett váladék: HSV 2 pozitív.

- Diagnosztizált trichomonasinfekció.

Bizonyitott bántalmazás, vagy szexuális érintkezés

- Vizsgálati leletben egyértelmủ a behatolás, erőszak nyoma, baleseti anamnézis nélkül.

- Spermium vagy prosztataváladék a gyermek testén vagy a testnyílásban.

- Terhesség.

- Neisseria gonorrhoea pozitív tenyésztés a genitális, anális vagy garatváladékból.

- Posztnatálisan szerzett szifilisz.

- Tanúk előtt zajló, vagy fényképpel, videofelvétellel dokumentált bántalmazás.

- Az elkövető vallomást tesz a szexuális bántalmazásra vonatkozóan.

- HIV-fertőzés, egyéb fertőzési módok kizárása után.

nyítékok gyüjtését ki kell egészíteni a teljes testen végzett spermiumkereséssel, Woods-lámpa használatával. Gondoskodni kell a DNS-teszt elérhetőségéről az összegyüjtött váladékok vizsgálata érdekében.

- Az áldozattal készült anamnézisfelvétel speciális szobában, interjúszakértő által végzett módon történjen, a beszélgetést videóra kell rögzíteni. 
- A bántalmazott gyermek ellátását egy multidiszciplináris csapat végezze, amelynek tagjai: orvos, szociális munkás, védőnő, gyermekjóléti szakszolgálat munkatársa, pszichiáter, pszichológus, rendőr, ügyész. A csapat tagjai időszakos rendszerességgel közösen megbeszélik a folyamatban lévő ügyeket. A csapat tagjait, és feladataikat az 5. számú táblázat ismerteti. ${ }^{15}$

Jogi szabályozás megalkotása: a nyomozástól a bírósági tárgyalásig gyermekbarát rendszert kell kialakítani, hiszen a fiatalkorúak első találkozása az igazságszolgáltatással az egész életükre kihat. Az egész jogrendszerben szemléletváltásra van szükség azért, hogy a sértettek megfelelő bánásmódban részesüljenek, és később ne váljanak maguk is bünözővé. A fiatalokkal kapcsolatos bánásmód javításának eszközei:

- gyermekeket érintő ügyek ténylegesen is soronkívüliséget élvezzenek;

- bírósági ügyek gyorsítása;

- életkornak megfelelő nyelvezet használata ${ }^{16}$;

- zárt kihallgatások megteremtése: áldozatbarát eljárási gyakorlat bevezetése, a videóra vett vallomást használják a bizonyítási eljárás során reviktimizáció elkerülése céljából;

- áldozatsegítés;

- bírói képzés kialakítása, amely a szükséges büntető anyagi és -eljárásjogi ismereteken túl sokkal szélesebb és mélyebb aspektusokból - a nemzetközi jogtól a pszichológiai eredményekig terjedően - közelítene a fiatalkorúakhoz;

- külön jogszabály írja le, hogy kinek és milyen formában kell a szexuális bántalmazást bejelenteni.

A mai magyar joggyakorlatban az elkövetők általában szabadlábon védekeznek, és a bántalmazó családtag egy fedél alatt marad áldozatával. Ez növeli az ismételt bántalmazás valószínüségét.

Prospektív tanulmányok végzése, amelyek egészen felnőttkorig követnék a gyermekáldozat sorsát. Ez nyújtaná a legnagyobb segítséget a gyermeket érő szexuális bántalmazás hatásának vizsgálatában.

Nem szabad elfeledkeznünk a fiú áldozatokról sem.

15 Angelo P. Giardino - Stephen Ludwig: Roles and responsibilities of professional team members In: Martin A. Finkel - Angelo P. Giardino (eds.): Medical Evaluation of child sexual abuse. 2nd ed. Sage Publ., Thousand Oaks, 2002, Chapter 11, pp. 215-231.

16 Elek Balázs: Az életkor jelentősége a gyermekkorú tanúk kihallgatásakor a büntetőeljárásban. Rendészeti Szemle, 2011/3., 93-111. o. 
5. számú táblázat

A multidiszciplináris csoport tagjai és azok szerepe

\begin{tabular}{|c|c|c|}
\hline szakma & feladat & képzettség \\
\hline $\begin{array}{l}\text { Nőgyógyász, } \\
\text { gyermekgyógyász, } \\
\text { gyermeknőgyógyász }\end{array}$ & $\begin{array}{l}\text { - A szexuális bántalmazás felismerése } \\
\text { és jelentése. } \\
\text { - Orvosi fizikális vizsgálat kivitelezése } \\
\text { és igazságügyi bizonyítékok gyüjtése. } \\
\text { - Az áldozat orvosi kezelése, a gyer- } \\
\text { mek és családja egészségének } \\
\text { helyreállítása. } \\
\text { - A kockázatos esetek követése. } \\
\text { - Tanúskodás a bíróságon az általa } \\
\text { végzett vizsgálat és gyűjtött } \\
\text { bizonyítékok felhasználásával. } \\
\text { - A szexuális zaklatással foglalkozó } \\
\text { egészségügyi és nem egészségügyi } \\
\text { szakemberek oktatása. }\end{array}$ & $\begin{array}{l}\text { A gyermekek ellen elkövetett szexuális } \\
\text { büncselekmények felismerésének és } \\
\text { kezelésének ismerete }\end{array}$ \\
\hline Védőnő & $\begin{array}{l}\text { - A családi körülmények észlelése, a } \\
\text { gyermek veszélyeztetettségének felis- } \\
\text { merése. }\end{array}$ & $\begin{array}{l}\text { Az egészséges gyermek korspecifikus } \\
\text { jellemzőinek ismerete }\end{array}$ \\
\hline Szociális munkás & $\begin{array}{l}\text { - Családi környezet felmérése. } \\
\text { - Kapcsolattartás a gyermekvédelmi } \\
\text { szolgálattal, a rendőrséggel, illetve } \\
\text { szükség esetén a gyermekorvossal és } \\
\text { a védőnővel. }\end{array}$ & $\begin{array}{l}\text { Gyermek fejlődésének, gyermekbántal- } \\
\text { mazás jellegének és a jogi szabályozás- } \\
\text { nak az ismerete. Interjúkészítés, infor- } \\
\text { mációgyüjtés módjának ismerete }\end{array}$ \\
\hline $\begin{array}{l}\text { Gyermekvédelmi } \\
\text { szervek }\end{array}$ & $\begin{array}{l}\text { - Bejelentések gyűjtése. } \\
\text { - A gyermek családból való } \\
\text { kiemelésének elindítása. } \\
\text { - Kapcsolattartás a nyomozati szakban } \\
\text { részt vevő szakmákkal. } \\
\text { - Egyéni támogatás. } \\
\text { - A család és a gyermek figyelemmel } \\
\text { kísérése a megelőzés érdekében. }\end{array}$ & $\begin{array}{l}\text { Jogi ismeretek } \\
\text { Együttmüködési készség } \\
\text { Gyermekelhelyezés, gyermekvédelem }\end{array}$ \\
\hline Rendőrség & $\begin{array}{l}\text { - Azonnali beavatkozás a gyermek } \\
\text { érdekében, és a gyermek védelme. } \\
\text { - Nyomozás és bizonyítékszerzés. }\end{array}$ & Nyomozati ismeretek \\
\hline Ügyész & $\begin{array}{l}\text { - A büntetőügyi eljárás során a gyer- } \\
\text { mek védelme, pszichés károsodások } \\
\text { megelőzése. }\end{array}$ & Speciális szakismeretek \\
\hline Ügyvéd & $\begin{array}{l}\text { - A gyermek szükségleteinek és } \\
\text { érdekeinek védelme az eljárás } \\
\text { folyamán. }\end{array}$ & Speciális szakismeretek \\
\hline
\end{tabular}




\begin{tabular}{|c|c|c|}
\hline Pszichológus & $\begin{array}{l}\text { - A bántalmazásnak kitett gyermek } \\
\text { felismerése (exploráció). A gyermek } \\
\text { mentális egészségének felmérése. Az } \\
\text { észlelt leletek helyes interpretálása. } \\
\text { Újabb bántalmazás kockázatának } \\
\text { meótélése }\end{array}$ & $\begin{array}{l}\text { A gyermekkel kapcsolatban levő } \\
\text { személyek (óvónő, tanár) és szerepük } \\
\text { ismerete }\end{array}$ \\
\hline
\end{tabular}

Minden cselekedetünkben arra gondoljunk, hogy a gyerekek és fiatalok nem tárgyak. Nem csak statisztikai adatok vagy ügyek. Ök a kapocs a jelen és a jövő között. Nem veszíthetjük el őket. Ez közös felelösségünk.

\section{Zárógondolatok}

Gyakorisága, súlyos egészségkárosító hatása és az áldozatok egész életre kiható következményei miatt az elmúlt évtizedekben az orvosi és a büntetőjogi gyakorlat középpontjába került a fiatalkorúak ellen elkövetett szexuális bántalmazás.

$\mathrm{Az}$ előbbiekben a Debreceni Egyetem Orvos- és Egészségtudományi Centrumának Szülészeti és Nőgyógyászati Klinikájának gyermeknőgyógyászati rendelésén az 1986. január 1. és 2006. december 31. között megjelent tizennyolc évesnél fiatalabb szexuálisan bántalmazott lányok adatait elemeztük.

Elmondható, hogy a gyermekek elleni szexuális bántalmazással foglalkozó kutatások nagy utat tettek meg az elmúlt harminc évben. A gyermekek elleni szexuális bántalmazás már nem egy „,másik izolált gyermekgyógyászati kórkép”, mint ahogy Kempe állította 1978-ban. ${ }^{17}$ A nyolcvanas években a bántalmazás bizonyításában még meghatározó szerepe volt a hymenális gyürü átmérőjének, ma már elavult mérésnek számít. Szembetűnő a szexuális bántalmazáson áteső áldozatok vizsgálata során talált pozitív fizikai leletek gyakoriságának csökkenése. Míg a nyolcvanas években az esetek ötven százalékában volt fizikai lelet, a kilencvenes években már csak húsz százalékban, jelenleg ez az arány tíz százalék. Ez az azóta kidolgozott, nagy létszámú áldozatot felölelő tanulmányok megjelenésének is tulajdonítható. Az évek folyamán összegyült tapasztalat és a diagnosztika fejlődése nyomán rendszereződtek a bántalmazásra gyanús és nem gyanús fizikai leletek. A média hatására megnőtt az odafigyelés, előtérbe került a szexuális bántalmazás kérdése,

17 C. Henry Kempe: Sexual abuse, another hidden pediatric problem: the 1977 C. Anderson Aldrich lecture. Pediatrics, vol. 62, 1978, pp. 382-389. 
mindez szintén nagy lökést adott az esetek felszínre kerülésének. Mindazonáltal az elkövetők módszere is változik: óvszert használnak, megakadályozva ezzel a bizonyítás idején oly fontos spermiumkutatást.

A változó elkövetési módszerek miatt is megállapítható, hogy hazánkban a tizennyolc évesnél fiatalabbak szexuális bántalmazásának egészségügyi ellátása, társadalmi megítélése egyaránt elégtelen, ez esetenként a megvalósuló büncselekmény bizonyításában is megmutatkozik. ${ }^{18}$ Hiányoznak a felismerést segítő eszközök, a diagnózis tárgyi és személyi feltételei, és az ellátásban részt vevő szakemberek, a gyermekekkel foglalkozó és értük felelős felnőttek (szülők, nevelők) felkészültsége is elégtelen.

18 Elek Balázs: A gyermekek sérelmére elkövetett szexuális büncselekmények büntetőjogi megítélésének egyes gyakorlati kérdései. Börtönügyi Szemle, 2003/4., 19-26. o. 